\title{
Correction to: The Effect of Language on Political Appeal: Results from a Survey Experiment in Thailand
}

\author{
Jacob I. Ricks ${ }^{1}$ (i)
}

Published online: 20 October 2018

(c) Springer Science+Business Media, LLC, part of Springer Nature 2018

\section{Correction to: Political Behavior https://doi.org/10.1007/s11109-018-9487-z}

The original version of this article contained a typo in the Introduction section. The Indonesian presidential candidate Prabowo Subianto was incorrectly identified as Prabowo Wiranto in the submitted and published version of the paper.

The original article can be found online at https://doi.org/10.1007/s11109-018-9487-z.

Jacob I. Ricks

jacobricks@smu.edu.sg

1 School of Social Sciences, Singapore Management University, 90 Stamford Road, Level 04, Singapore 178903, Singapore 